\title{
Spring planting favors yield of new Brazilian potato cultivar BRS F63 Camila
}

\author{
Vlandiney Eschemback ${ }^{1} \mathbb{D}$; Jackson Kawakami ${ }^{1} \mathbb{D}$; Aline M Genú ${ }^{1} \mathbb{D}$; Leonardo Z Anderle ${ }^{1 \mathbb{D}}$ \\ 'Universidade Estadual do Centro-Oeste (UNICENTRO), Departamento de Agronomia, Guarapuava-PR, Brasil; jkawakami@unicentro.br.
}

\begin{abstract}
The objective of this work was to evaluate the effect of different planting dates on the morphological variables and yield of new potato cultivars. The treatments were three cultivars (Agata, BRS Clara and BRS F63 Camila) and three planting date (October, December and February), carried out in two crop years (2014/15 and 2015/16). Total and marketable yields, average mass of total and marketable tubers, growth period, leaf area index, number and dry weight of the tubers were evaluated. The first planting date resulted in higher yield than the third date. Cultivar BRS F63 Camila was the one with highest yield in this first planting date $\left(47.4 \mathrm{tha}^{-1}\right)$, due to greater number of tubers produced in relation to the other cultivars and to higher average tuber weight $\left(166 \mathrm{~g}_{\text {tuber }}^{-1}\right)$ in relation to Agata $\left(113 \mathrm{~g} \mathrm{tuber}^{-1}\right)$. In the second planting date, no difference in yield was observed among cultivars. In the third planting date, BRS Clara was the cultivar with highest yield (21.3 $\left.\mathrm{tha}^{-1}\right)$, due mainly to higher average weight of tubers $\left(105 \mathrm{~g} \mathrm{tuber}^{-1}\right)$ in relation to Agata $\left(49 \mathrm{~g} \mathrm{tuber}^{-1}\right)$, a fact favored by the higher leaf area index and longer growth period of BRS Clara. Depending on the planting date, one should choose the cultivar that results in maximum yield potential, since it is a plant management with low cost and high yield impact. For the second planting date, any of the studied cultivars can be used.
\end{abstract}

Keywords: Solanum tuberosum, planting date, tuber yield, zoning.

\section{RESUMO}

Plantio de primavera favorece produtividade de nova cultivar de batata brasileira BRS F63 Camila

O objetivo deste trabalho foi avaliar o efeito de diferentes épocas de plantio nas variáveis morfológicas e na produtividade de novas cultivares de batata. Os tratamentos foram três cultivares (Ágata, BRS Clara e BRS F63 Camila) e três épocas de plantio (outubro, dezembro e fevereiro), realizados em duas safras agrícolas (2014/15 e 2015/16). Avaliou-se a produtividade total e comercial, a massa média de tubérculo total e comercial, o período de crescimento das plantas, o índice de área foliar, o número e a massa seca dos tubérculos. A primeira época de plantio resultou em maior produtividade que a terceira época. A cultivar BRS F63 Camila foi aquela com maior produtividade nessa primeira época de plantio $\left(47,4 \mathrm{t} \mathrm{ha}^{-1}\right)$, devido ao maior número de tubérculos produzidos em relação às demais cultivares e ao maior peso médio de tubérculos (166 $\mathrm{g}$ tubérculo $\left.{ }^{-1}\right)$ em relação à Ágata $\left(113 \mathrm{~g}\right.$ tubérculo $\left.{ }^{-1}\right)$. Na segunda época de plantio, não houve diferença na produtividade entre as cultivares. $\mathrm{Na}$ terceira época de plantio, a cultivar BRS Clara apresentou a maior produtividade $\left(21,3 \mathrm{tha}^{-1}\right)$, devido principalmente ao maior peso médio dos tubérculos (105 $\mathrm{g}$ tubérculo $\left.{ }^{-1}\right)$ em relação à Ágata (49 $\mathrm{g}_{\text {tubérculo }}{ }^{-1}$ ), fato favorecido pelo maior índice de área foliar e maior período de crescimento da cultivar BRS Clara. Dependendo da época de plantio, deve-se escolher a cultivar que resulte em máximo potencial produtivo, já que é um manejo das plantas com baixo custo e alto impacto na produtividade. Para a segunda data de plantio, qualquer uma das cultivares estudadas pode ser utilizada.

Palavras-chave: Solanum tuberosum, época de plantio, produtividade de tubérculo, zoneamento.

\section{Received on February 11, 2019; accepted on October 7, 2019}

$\mathrm{D}$ ue to the nutritional quality of its tubers, potato (Solanum tuberosum) is of great importance as a food source for human populations (Evangelista, 2011). Because of its high yield, this crop occupies great areas intended for food production (Fernandes et al., 2010).

The main potato planting dates in southern Brazil are in spring, when rainfall is concentrated, and planting is carried out from August to December, and in autumn, when the drought period is concentrated and planting is carried out from February to June (Pereira, 2008).

These two planting dates result in variable climatic conditions affecting, consequently, the agronomic characteristics of plants grown in this region. Spring planting is characterized by increasing photoperiod, air temperature and solar radiation and, on the contrary, fall planting is characterized by decreasing photoperiod, air temperature and solar radiation (Simepar, 2018). These factors influence directly the physiology of the potato plants and, therefore, affect tuber metabolism, which may limit the yield potential and quality of the tubers. High air temperature results in reduced photosynthetic rate, increased respiration and reduced leaf area index (Fagundes, 2010). Long photoperiod can even prevent tuberization (Bisognin 
\& Douches, 2002).

The majority of potato cultivars used in Brazil is of foreign origin, especially from the European continent, from temperate climate countries. In order to meet the specific demands of the market, cultivars have been imported from countries such as the Netherlands, Sweden, Germany and Canada. In Brazil, however, there are Brazilian cultivars available in the market, released recently by government research institutions (Pereira et al., 2015), but with low adoption and often unknown to a large part of Brazilian producers (Feltran \& Lemos, 2005).

Potato cultivars may respond differently to changes in photoperiod, temperature and solar radiation (Kleinwachter et al., 2016; Raymundo et al., 2017). Therefore, adjustment of the cultivar for the planting date is an inexpensive way to optimize potato yield. Furthermore, this adjustment is important to generate plant management information to national potato producers, encouraging the adoption of cultivars developed by breeding programs in the country.

The objective of this work was to evaluate the effect of different planting dates on the morphological variables and yield of new potato cultivars.

\section{MATERIAL AND METHODS}

The experiment was carried out in Guarapuava-PR, Brasil, in the experimental field of Universidade Estadual do Centro-Oeste (UNICENTRO) $\left(25^{\circ} 23^{\prime} 04\right.$ ' $\mathrm{S}$ and $51^{\circ} 29^{\prime} 36^{\prime \prime} \mathrm{W}$ ), in the crop years $2014 / 15$ and $2015 / 16$. The soil at the site is classified as a Typic Hapludox (Michalovicz et al., 2014). The soil (0-20 $\mathrm{cm})$ chemical analyses, before planting date of the experiments, revealed in the crop year 2014/15: $\mathrm{pH}\left(\mathrm{CaCl}_{2}\right)=4.8$; $\mathrm{P}($ Mehlich $)=2.3 \mathrm{mg} \mathrm{dm}^{-3} ; \mathrm{K}=0.20$ $\mathrm{cmol}_{\mathrm{c}} \mathrm{dm}^{-3} ; \mathrm{Al}=0.0 \mathrm{cmol}_{\mathrm{c}} \mathrm{dm}^{-3} ; \mathrm{Ca}=$ $3.5 \mathrm{cmol}_{\mathrm{c}} \mathrm{dm}^{-3} ; \mathrm{Mg}=1.8 \mathrm{cmol}_{\mathrm{c}} \mathrm{dm}^{-3}$; cation exchange capacity $(\mathrm{CEC})=11.5$ $\mathrm{cmol}_{\mathrm{c}} \mathrm{dm}^{-3}$ and base saturation $(\mathrm{V})=$ $48 \%$. For the crop year 2015/16 the following data were observed: $\mathrm{pH}$ $\left(\mathrm{CaCl}_{2}\right)=5.0 ; \mathrm{P}($ Mehlich $)=3.1 \mathrm{mg} \mathrm{dm}^{-3}$;
$\mathrm{K}=0.20 \mathrm{cmol}_{\mathrm{c}} \mathrm{dm}^{-3} ; \mathrm{Al}=0.0 \mathrm{cmol} \mathrm{dm}_{\mathrm{c}}$; $\mathrm{Ca}=2.9 \mathrm{cmol}_{\mathrm{c}} \mathrm{dm}^{-3} ; \mathrm{Mg}=1.9 \mathrm{cmol}_{\mathrm{c}} \mathrm{dm}^{-3}$; $\mathrm{CEC}=9.2 \mathrm{cmol}_{\mathrm{c}} \mathrm{dm}^{-3}$ and $\mathrm{V}=54 \%$. Based on these results, we calculated the need for liming to achieve $\mathrm{V}$ of $60 \%$, which was performed three months prior to planting with dolomitic limestone filler, incorporated into the soil in both crop years (Sociedade Brasileira de Ciência do Solo, 2017).

The treatments consisted of three planting dates (October, December and February) and three potato cultivars [Agata (control); BRS Clara, released in 2010 and BRS F63 Camila, released in 2015], carried out in two crop years (2014/15 and 2015/16). The experimental design was randomized blocks in split-plot scheme, with the crop years and planting date allocated in the plot, and the cultivars in the subplots, with three repetitions. Each subplot measured $8.0 \times 4.5 \mathrm{~m}$ and was composed by 10 rows, 18 plants per row, and spacing of $0.80 \mathrm{~m}$ between rows and $0.25 \mathrm{~m}$ between plants.

The seed-tubers of cultivars BRS Clara and BRS F63 Camila of the first crop year (2014/15) were provided by Embrapa Produtos e Mercado (Canoinhas-SC) and the seed-tubers of cultivar Agata were supplied by producer of certified seeds in the region of Guarapuava, Brasil. The seed-tubers measured 30 to $40 \mathrm{~mm}$ in diameter.

In the second crop year (2015/16), the seed-tubers of all cultivars were originated from the first crop year, being harvested manually in each planting date and standardized for size $(30-40 \mathrm{~mm})$, physiological age and phytosanitary health. The seed-tubers were stored in cold chamber at $4^{\circ} \mathrm{C}$ until approximately 40 days prior to planting.

Planting and management of experimental area

The soil was prepared one month prior to the implementation of the crop with one subsoiling and two harrowings. On the planting date, a light harrowing was performed with posterior plowing of the area. The fertilizer NPK 04-14-08 at $4 \mathrm{tha}^{-1}$ was distributed in total dose in the furrow, immediately before the tubers manual planting, providing 160 $\mathrm{kg} \mathrm{ha}^{-1}$ of $\mathrm{N}, 560 \mathrm{~kg} \mathrm{ha}^{-1}$ of $\mathrm{P}_{2} \mathrm{O}_{5}$ and $320 \mathrm{~kg} \mathrm{ha}^{-1}$ of $\mathrm{K}_{2} \mathrm{O}$, quantity of nutrients found as a sum quite close to the dose of maximum technical efficiency for the culture in the region of GuarapuavaPR (Queiroz et al., 2013). Hilling was performed in both crop years and planting dates, approximately 15 days after plant emergence (DAE). The controls of major diseases (Phytophtora infestans and Alternaria solani) and pest (Diabrotica speciosa) were performed in accordance with the technical recommendations of the region for the cultivation (Pereira \& Daniels, 2003) in two crop years. The field trial was not irrigated.

\section{Quantification of the analyzed variables}

The meteorological date during the period of the experiments (air temperature, precipitation and solar radiation), as well as the historical average, were obtained from the Parana Meteorological System (SIMEPAR), meteorological station located approximately $100 \mathrm{~m}$ from the experiment site.

Plant emergence was defined as the date when there was $75 \%$ emergency. The number of emerged plants per plot was obtained at intervals of 2-3 days. Senescence was counted when $75 \%$ of the plant stems were dry, being the growth period determined as the interval between the emergence and senescence.

At 15, 30, 45 and $60 \mathrm{DAE}$, stages of tuber initiation, flowering, maximum shoot growth and tuber bulking, respectively, the leaf area index (LAI), the number of tubers formed $\left(\mathrm{m}^{2}\right)$ and the dry weight of tubers of 4 plants per plot of 4 central rows were quantified. For the determination of dry weight, samples were placed in an oven with forced air circulation at $70^{\circ} \mathrm{C}$ until constant weight for later weighing. We considered formed tubers those greater than $1 \mathrm{~cm}$ diameter. LAI was estimated by means of quantification of the leaf area of sub samples of leaves, approximately $2,000 \mathrm{~cm}^{2}$ (Licor, LI 3100 , USA). With the obtained leaf area and dry weight of this sub sample, and the leaf dry weight of leaves of 4 collected plants and the planting density, the LAI of each plot was estimated.

In order to quantify the tuber yield, we counted the number and weighing 
of all tubers harvested in the plot (total production in number of tubers and $\mathrm{kg}$ plot $^{-1}$ ) and counting and weighing the normal tubers (without defects) with a diameter greater than $45 \mathrm{~mm}$ of marketable tubers (number of tubers

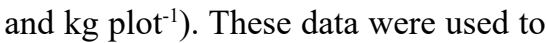
estimate the mean tuber weight of both categories, as well as the estimated yield per hectare.

\section{Statistical analysis}

The Shapiro-Wilk's test for normality was applied, and when necessary the data that showed non-normal distribution (LAI of cultivar Agata at 45 and $60 \mathrm{DAE}$ at third planting date) passed by Box-Cox transformation. The analysis of variance (ANOVA) and the comparison of means by Tukey's test $(p<0.05)$ were performed.

\section{RESULTS AND DISCUSSION}

Regarding the meteorological data, the average temperatures in 2014/15 were similar to those observed in the crop year 2015/16, except for the months November, February and April. The temperature was higher in November in the crop year 2014/15 compared to $2015 / 16$, but in February and April the opposite was observed (Figure 1a). Higher initial temperature was observed in the period that comprises the third planting date, in both crop years. The temperature on the two planting years, was much higher, in relation to the average values of the 30 last years, confirming the warming of the atmosphere. The year 2014/15, although with higher temperature, followed the same trend of the observed curve in the average of the 30 last years. We observed that, in the crop year $2014 / 15$, there was less rainfall $(1,436 \mathrm{~mm})$ compared to the crop year 2015/16 (1,649 $\mathrm{mm})$, except what occurred during September, January and February (Figure 1b). The average solar radiation in the crop year $2014 / 15\left(564 \mathrm{MJ} \mathrm{m}^{-2}\right)$ was similar to that observed in the crop year 2015/16 (538 $\mathrm{MJ} \mathrm{m}^{-2}$ ) (Figure 1c), increasing between September and January and decreasing from February to May.

No difference was observed in the total and marketable tuber yield between the crop years, but there was an interaction between planting date and cultivar (Table 1). In the first planting date, BRS Camila presented higher total yield and there was no difference between Agata, and BRS Clara (Figure 2a). In the second planting date no difference was observed between cultivars. However, in the third planting date, BRS Clara presented higher total yield than cultivar Agata, and BRS F63 Camila with intermediate yield (Figure 2a). The same trend was observed for the marketable tuber yield (Figure 2b).

The yields obtained in this study are close to those found in other studies for cv. Agata, with average yield of $41 \mathrm{t}$ ha $^{-1}$ (Queiroz et al., 2013; Eschemback et al., 2017). For BRS Clara, other authors obtained total yield of $18.9 \mathrm{t}$

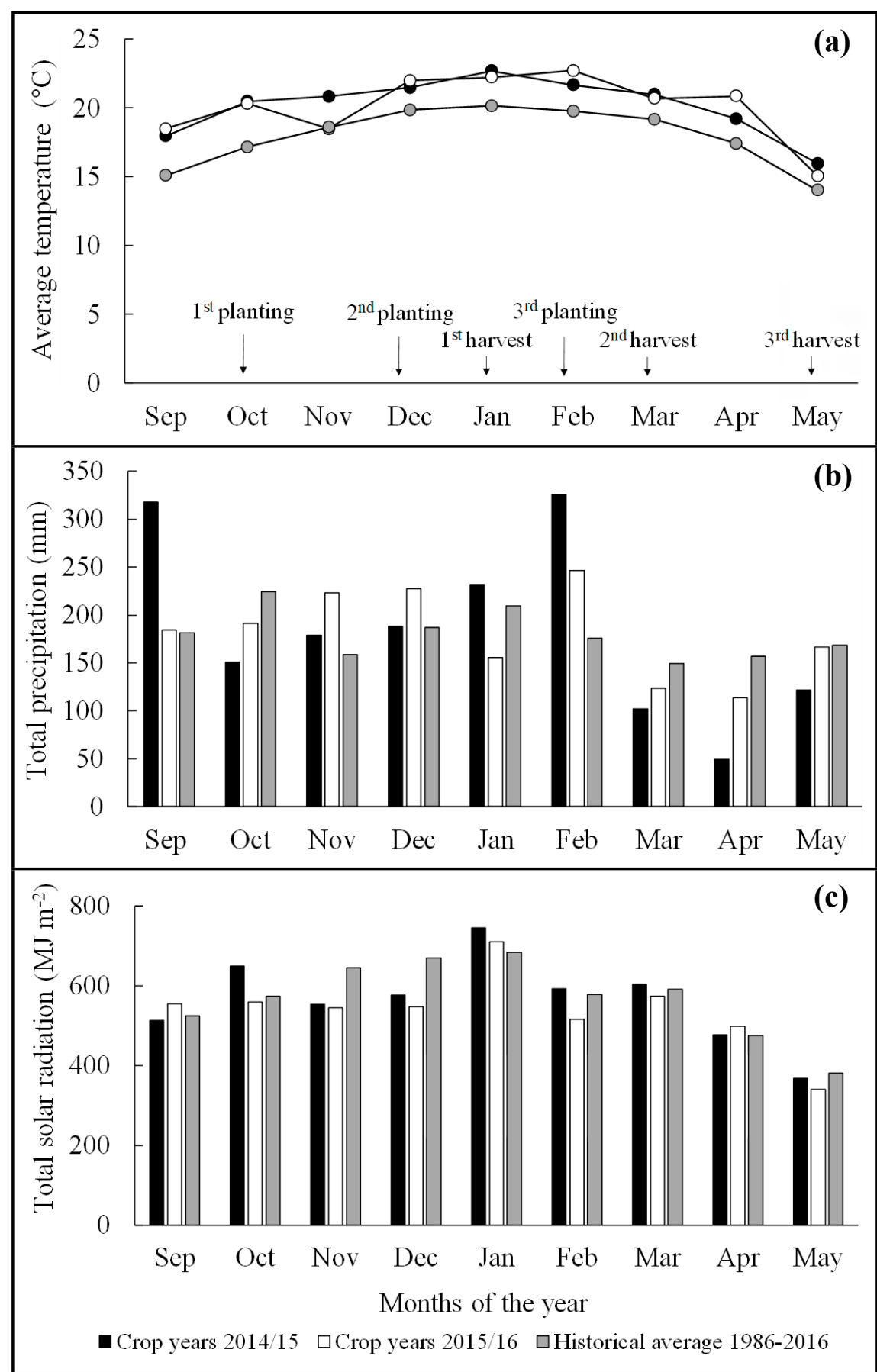

Figure 1. Monthly average temperature $\left({ }^{\circ} \mathrm{C}\right)$, total precipitation $(\mathrm{mm})$ and total solar radiation $\left(\mathrm{MJ} \mathrm{m}^{-2}\right.$ ), in the crop years 2014/15 and 2015/16. Source: Simepar (historical average from 1986 to 2016). Guarapuava, UNICENTRO, 2014-2016. 
ha $^{-1}$ and marketable yield of $11.0 \mathrm{tha}^{-1}$ (Pereira et al., 2013). In the same study Agata obtained total yield of $13.3 \mathrm{tha}^{-1}$ and marketable yield of $7.4 \mathrm{tha}^{-1}$; these values are lower than those observed for the cultivars in the first and second planting date in the present work, but similar to that found in the third planting date. In spite of the yield observed in the third planting dates of the present study being low if compared to the first and second planting dates, they are within the ones observed for the crop in other studies.

Difference was observed for the total number of tubers between the crop years 2014/15 (29 tubers $\mathrm{m}^{-2}$ ) and 2015/16 (32 tubers $\mathrm{m}^{-2}$ ), this difference was not observed for the number of marketable tubers (Table 1). There was an interaction between planting date and cultivar, both for the total and marketable tubers. Agata produced greater number of total tubers than BRS Clara at all planting dates (Figure 2c). On the other hand, BRS F63 Camila produced the same amount of total tubers compared with Agata in the first planting date and lower in the second, and BRS F63 Camila produced a smaller number than BRS Clara in the third planting date. In the first planting date we observed a greater number of marketable tubers for Agata (Figure 2d), lower for the BRS Clara and intermediary number for BRS F63 Camila. In the second planting date no differences were observed among cultivars, however, in the third planting date BRS Clara produced greater number of marketable tubers, Agata produced lower number and BRS F63 Camila intermediate number of tubers (Figure 2d).

No difference between the crop years was observed for average weight of marketable tubers, but there was an interaction between planting date and cultivar (Table 1). Agata presented the lowest average weight of tubers, both total (Figure 2e) and marketable (Figure 2f) among the evaluated cultivars in three planting dates. The cultivars produced tubers with lower average weight on the third planting date in comparison with the first, and this reduction in the average weight was more pronounced for BRS F63 Camila.

Verifying the LAI development, interaction was observed between planting date and crop year at 15 and $30 \mathrm{DAE}$, and between planting date and cultivar at 45 and 60 DAE, in addition to isolated effect of cultivar at 30 DAE and crop year at $60 \mathrm{DAE}$ (Table 1). However, Agata differed from the evaluated cultivars with the lowest LAI in the first date at 45 and 60 DAE. The same trend was observed for LAI of cultivars in the third planting date at 45 and 60 DAE. In general, the later the planting date, the lower the LAI of cultivars at 45 and $60 \mathrm{DAE}$, mainly for

Table 1. p-value of the analysis of variance of the variables evaluated during the experiments in the crop years 2014/15 and 2015/16. Guarapuava, UNICENTRO, 2014-2016.

\begin{tabular}{|c|c|c|c|c|c|c|c|c|c|}
\hline P-value & $\begin{array}{c}\text { Year } \\
(\mathbf{Y})\end{array}$ & $\begin{array}{c}\text { Cultivar } \\
\text { (C) }\end{array}$ & $\mathbf{Y} \times \mathbf{C}$ & $\begin{array}{l}\text { CV1 } \\
(\%)\end{array}$ & $\begin{array}{l}\text { Date } \\
\text { (D) }\end{array}$ & $D \times Y$ & $D \times C$ & $D \times Y \times C$ & $\begin{array}{l}\text { CV2 } \\
(\%)\end{array}$ \\
\hline TY $\left(\mathrm{kg} \mathrm{ha}^{-1}\right)$ & 0.030 & 0.016 & 0.260 & 11.9 & $<0.001$ & 0.067 & 0.011 & 0.904 & 18.1 \\
\hline MY $\left(\mathrm{kg} \mathrm{ha}^{-1}\right)$ & 0.059 & 0.007 & 0.234 & 14.1 & $<0.001$ & 0.023 & 0.015 & 0.750 & 19.5 \\
\hline $\mathrm{TNT}\left(\mathrm{m}^{2}\right)$ & 0.041 & $<0.001$ & 0.829 & 9.2 & $<0.001$ & 0.661 & 0.003 & 0.578 & 14.6 \\
\hline $\operatorname{NMT}\left(m^{2}\right)$ & 0.352 & 0.868 & 0.345 & 16.1 & $<0.001$ & 0.435 & $<0.001$ & 0.515 & 14.4 \\
\hline AWTT (g tuber ${ }^{-1}$ ) & 0.997 & 0.002 & 0.211 & 15.2 & $<0.001$ & 0.003 & 0.045 & 0.084 & 15.9 \\
\hline AWMT (g tuber ${ }^{-1}$ ) & 0.091 & 0.001 & 0.241 & 12.0 & $<0.001$ & 0.120 & 0.041 & 0.243 & 13.7 \\
\hline PG (DAE) & 0.081 & $<0.001$ & 0.826 & 0.7 & $<0.001$ & 0.819 & $<0.001$ & 0.940 & 2.5 \\
\hline LAI (15 DAE) & 0.324 & 0.569 & 0.335 & 37.3 & $<0.001$ & $<0.001$ & 0.220 & 0.350 & 24.5 \\
\hline LAI (30 DAE) & 0.009 & 0.032 & 0.756 & 26.7 & $<0.001$ & $<0.001$ & 0.064 & 0.452 & 34.0 \\
\hline LAI (45 DAE) & 0.118 & $<0.001$ & 0.539 & 41.5 & $<0.001$ & 0.140 & $<0.001$ & 0.310 & 43.6 \\
\hline LAI (60 DAE) & 0.028 & $<0.001$ & 0.139 & 42.7 & $<0.001$ & 0.364 & $<0.001$ & 0.061 & 40.4 \\
\hline NTF (15 DAE) & 0.009 & 0.021 & 0.104 & 23.3 & $<0.001$ & 0.464 & 0.189 & 0.774 & 38.2 \\
\hline NTF (30 DAE) & 0.497 & 0.004 & 0.502 & 14.9 & 0.179 & 0.083 & 0.046 & 0.724 & 24.1 \\
\hline NTF (45 DAE) & 0.038 & 0.048 & 0.667 & 31.2 & 0.682 & 0.012 & 0.467 & 0.646 & 30.1 \\
\hline NTF (60 DAE) & 0.176 & 0.019 & 0.172 & 16.3 & 0.081 & 0.577 & 0.084 & 0.975 & 31.8 \\
\hline DWT (15 DAE) & 0.048 & 0.276 & 0.843 & 27.1 & $<0.001$ & $<0.001$ & 0.132 & 0.260 & 24.9 \\
\hline DWT (30 DAE) & 0.019 & 0.070 & 0.131 & 23.3 & $<0.001$ & 0.491 & 0.156 & 0.768 & 26.8 \\
\hline DWT (45 DAE) & 0.062 & 0.027 & 0.395 & 5.6 & $<0.001$ & 0.057 & 0.044 & 0.005 & 5.4 \\
\hline DWT (60 DAE) & 0.640 & 0.002 & 0.839 & 2.3 & $<0.001$ & 0.969 & 0.048 & 0.967 & 4.3 \\
\hline
\end{tabular}

${ }^{1}$ Total yield (TY), marketable yield (MY), total number of tubers (TNT), number of marketable tubers (NMT), average weight of total tuber (AWTT), average weight of marketable tubers (AWMT), growth period (GP), leaf area index (LAI), number of formed tubers (NFT), dry weight of tubers (DWT) and coefficient of variation $(\mathrm{CV})$. 


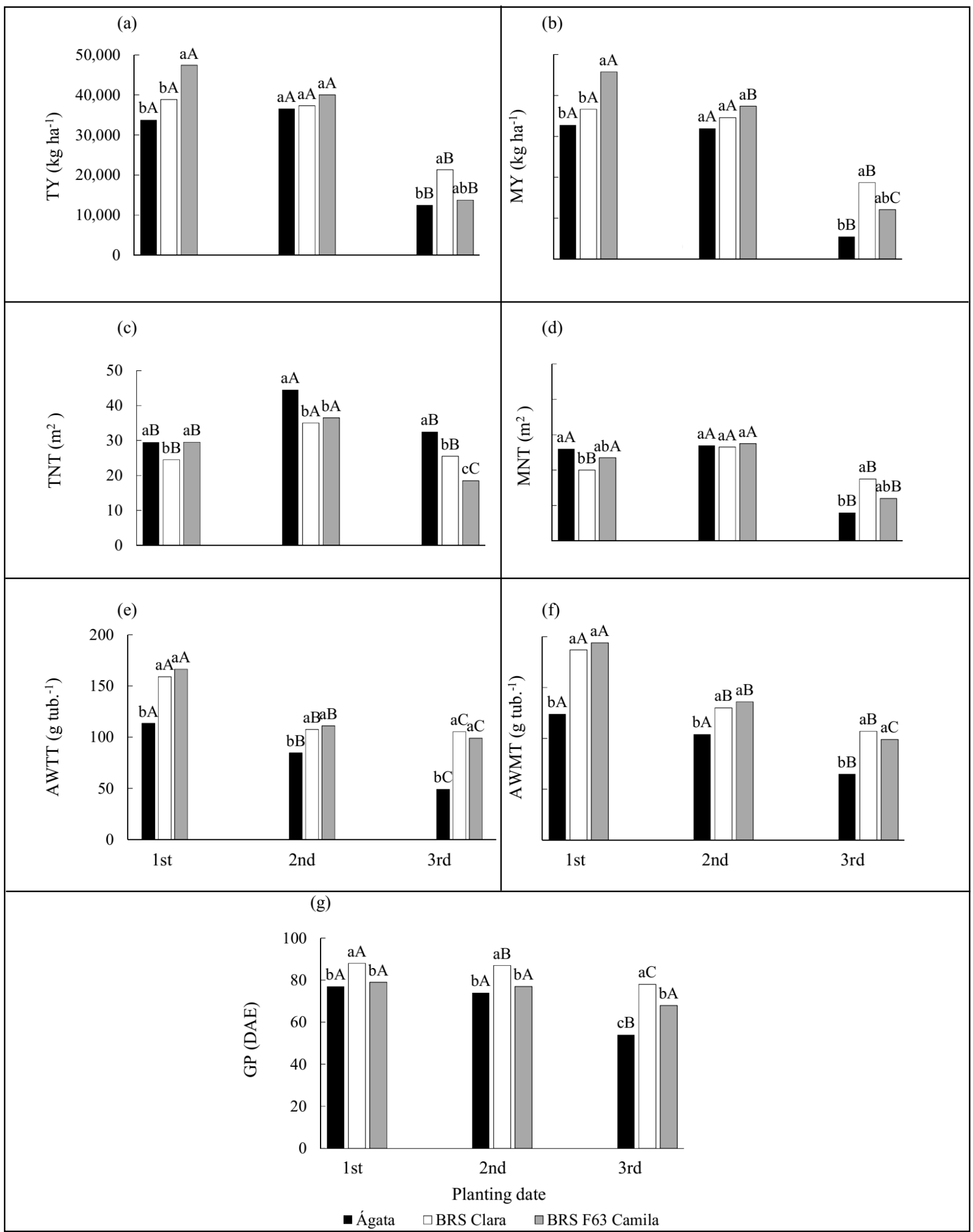

Figure 2. Total yield (TY) (a) and marketable yield (MY) $\left(\mathrm{kg} \mathrm{ha}^{-1}\right)(\mathrm{b})$, total number of tubers (TNT) (c) and marketable number of tubers $(\mathrm{MNT})\left(\mathrm{m}^{2}\right)(\mathrm{d})$, average weight of total tubers (AWTT) (e), average weight of marketable tubers (AWMT) (g tub $\left.{ }^{-1}\right)(\mathrm{f})$ and growth period (GP) (g) (DAE) of potato cultivars in different planting data in the crop years 2014/15 and 2015/16. ${ }^{1}$ Means followed by the same lowercase letters (at planting data) and uppercase letters (between planting data), do not differ significantly by Tukey test, $\mathrm{p}<0.05$. Guarapuava, UNICENTRO, 2014-2016 


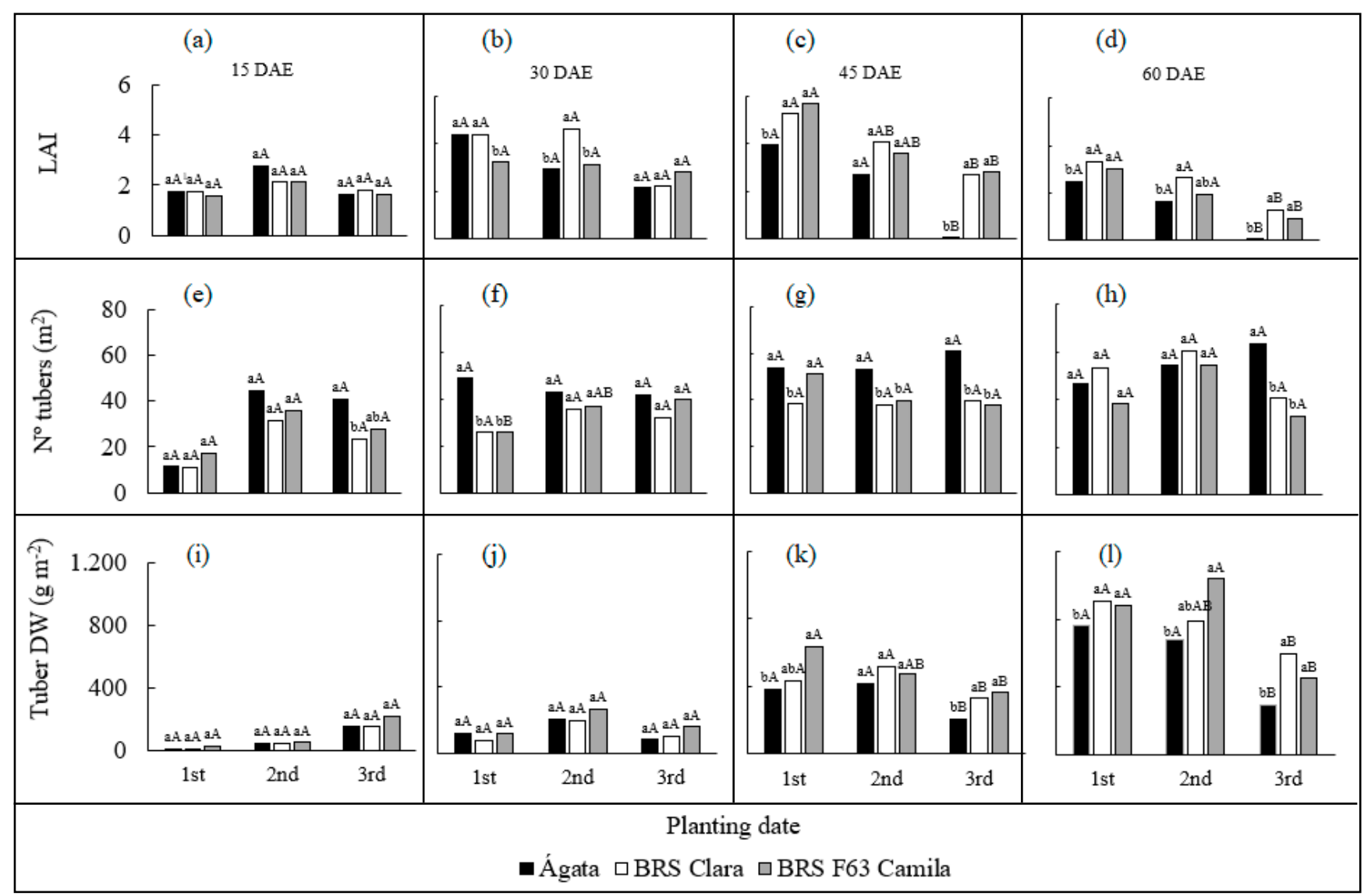

Figure 3. Leaf area index (LAI) (a), (b), (c) and (d), number of tubers (NTF) per area (e), (f), (g) and (h), and dry weight of tubers (DWT) (i), (j), (k) and (l) of potato cultivars as a function of days after plant emergence and different planting data in the crop years 2014/15 and 2015/16. ${ }^{1}$ Means followed by same lowercase letters (at DAE) and uppercase letters (between planting data), do not differ significantly by Tukey test, $\mathrm{p}<0.05$. Guarapuava, UNICENTRO, 2014-2016.

Agata (Figure 3c, 3d).

For the number of formed tubers, there was an interaction between planting date and cultivar at $30 \mathrm{DAE}$ and between planting date and year at 45 DAE. Also, an isolated effect of year was observed, cultivar and planting date at $15 \mathrm{DAE}$ and cultivar at 45 and 60 DAE (Table 1). Agata was the cultivar with the greatest number of formed tubers, mainly at $30 \mathrm{DAE}$ in the first planting date, at $45 \mathrm{DAE}$ in the second planting date and at 45 and $60 \mathrm{DAE}$ in the third planting date. BRS F63 Camila and BRS Clara formed a smaller number at $30 \mathrm{DAE}$ in the first planting date, at 45 DAE of the second and at 45 and 60 DAE of the third planting date, not differing among themselves (Figure $3 \mathrm{e}$, 3f, 3g, 3h).

The highest total and marketable yield of BRS F63 Camila in the first planting date (Figure 2a, 2b) is related to the greater number of total tubers produced by this cultivar compared to BRS Clara (Figure 1c), because both produced tubers with similar average weight (Figure 1e, 1f). The largest number of tubers produced by BRS F63 Camila at harvest was due to greater retention of tubers formed at $60 \mathrm{DAE}$ (Figure $3 \mathrm{~h}$ ), because at $60 \mathrm{DAE}$ there was no difference in the number of tubers formed between the cultivars. In fact, the energy expenditure for the tubers formation which are not filled by photoassimilates and do not reach the end of the cycle may have hampered the yield of BRS Clara in the first planting date. On the other hand, the higher yield in relation to Agata was due to higher average weight of tuber of BRS F63 Camila, because these cultivars produced similar number of tubers.

The smaller LAI of Agata from 45 DAE (Figure 3c, 3d), coupled with the larger number of produced tubers (Figure 2c, 2d) probably resulted in lower average weight of tubers of this cultivar (Zhang et al., 2012; Wang et al., 2015) (Figure 2e, 2f). Other studies also reported higher average weight of tubers of BRS F63 Camila compared to Agata (Silva et al., 2017), corroborating the result observed in the present study.

Plants that have a high number of tubers produce small tubers, a fact observed mainly for Agata, in the present study, indicating a high yield potential of this cultivar if the produced tubers had a better development (Silva et al., 2009).

Studies have reported that in the spring cultivation a positive correlation of dry weight of tubers with LAI was observed, confirming the hypothesis that cultivars with higher initial vigor, i.e., higher LAI and early tuberization (45 DAE) are more productive (Zanon et al., 2013). This fact can be observed with the LAI and dry weight of tubers of BRS F63 Camila and BRS Clara at 
45 and 60 DAE in the first planting date.

In the second planting date no difference was observed in the total and marketable yield among the studied cultivars (Paul et al., 2016), despite the production of a greater number of total tubers of Agata. This cultivar produced tubers with lower average weight, probably due to the lower LAI at 60 DAE, in the first and second planting date. In another study, no difference was observed in yield among cultivars Agata and BRS F63 Camila planted around the second planting date in the present study, carried out in 2 crop years (Santos et al., 2018). Thus, in the second planting date or in the late planting in spring it is possible to use any one of the studied cultivars as an option for planting. It is assumed that in this planting date less difference is found in yield among the different genotypes of potato.

We observed an interaction between planting date and the crop year at 15 DAE for dry weight of tubers, isolated effect of crop year and planting date at $30 \mathrm{DAE}$, triple interaction at $45 \mathrm{DAE}$ and interaction between planting date and cultivar at 60 DAE (Table 1). In the first date we observed higher dry weight of tubers for BRS F63 Camila at 45 DAE; at 60 DAE BRS F63 Camila and BRS Clara showed the highest values. Agata produced less tuber dry weight on the first and third planting date at 45 and 60 DAE (figure $3 \mathrm{k}, 31$ ). Lower accumulation of dry weight was observed of tubers from $45 \mathrm{DAE}$ in the third planting date compared to the first date (Figure 3k).

In the third planting date the highest yield of total tuber of BRS Clara in relation to Agata is related to a higher average weight of total tuber, because Agata produced greater number of total tuber than BRS Clara. Although Agata produced $22 \%$ more tubers than BRS Clara, the tubers of BRS Clara were 53\% heavier than those of Agata, contributing to higher yield of that cultivar. In the third planting date we observed that at 45 DAE, BRS Clara maintained higher LAI than Agata.

No effect was observed for the crop year, but there was an interaction between planting date and cultivar, between cultivars in the growth period (Table 1). A higher growth period was observed for BRS Clara at all planting dates (Figure 2g). Agata, and BRS F63 Camila had similar growth period, except at the third planting date in which Agata had lower growth period.

The longer growth period of BRS Clara in the third planting date, associated with greater LAI favored the greater accumulation of dry weight in the tubers. The increase of temperature leads to the decreases of growth period, dry matter accumulation, fresh weight of tubers and final yield (White \& Sanderson, 1983; Wang et al., 2015), fact observed mainly in the third planting date with cultivar Agata. BRS F63 Camila in the third planting date showed average weight of tubers similar to BRS Clara, but produced a smaller number of total tubers, obtaining intermediary yield among the studied cultivars.

When potato plants are grown under long photoperiod, they usually slow the onset of tuberization and have more abundant foliage with later growth period (Wang et al., 2015). However, the later the planting date, and higher the temperatures, the shorter the plant growth period (Hassanpanah et al., 2009; Arab et al., 2011). A greater growth period was observed on plants of the cultivar BRS Clara in all planting dates compared to BRS F63 Camila and Agata. However, in the third planting dates, the growth period of Agata had a greater reduction compared to other planting dates and cultivars. The longest growth period of BRS Clara in relation to Agata, can be advantageous because the greater longevity may represent a better utilization of environmental factors and higher accumulation of nutrients, favoring the higher yield (Narasimhamoorthy et al., 2013; Silva et al., 2013b).

In the present study a lower rainfall was observed in the third planting date (Figure 1b), and BRS Clara was more productive than Agata, both in the total yield of tubers as marketable ones (Figure 2a, 2b) and less variation in the average weight of tubers (Figure 2f) with the longest plant growth period (Figure 2g). Studies have reported that cultivar BRS Clara is tolerant to water shortage in the laboratory conditions, this tolerance was also tested and proven in field conditions (Silva et al., 2013a), being observed that the cultivars BRS Clara and Agata produced the same number of marketable tuber, however BRS Clara produced tubers with higher average weight, reflections of a certain drought tolerance of this cultivar.

Temperature is one of the main factors that influence the development and yield of potato crop (Haverkort \& Verhagen, 2008; Raymundo et al., 2017), because the majority of the cultivars used in the country have European origin, they may suffer the adverse effects, such as decrease in the growth period and reduction in yield and quality of the tubers (Menezes et al., 2001; Bisognin et al., 2008; Rykaczewska, 2015). Such fact was probably responsible for the reduction of the growth period and lower yield observed in plants conducted in the third planting date in the present study, being more pronounced to Agata in the same period, presenting the lowest total and marketable yields.

The morphological and yield variation of potato plants in response to different planting dates and cultivars demonstrates the importance of correct choice of cultivar for each planting date. Such management can increase in an inexpensive way the potato production in Southern Brazil. Depending on the planting date, the cultivar that will result in the maximum yield potential should be chosen, for the second planting date, any of the studied cultivars can be used.

\section{ACKNOWLEDGEMENTS}

This study was financed in part by the Coordenação de Aperfeiçoamento de Pessoal de Nível Superior - Brasil (CAPES) - Finance Code 001.

\section{REFERENCES}

ARAB, HR; AFSHARI, H; DALIRI, MS; LAEI, G; TOUDAR, SR. 2011. The effect of planting date, depth and density on yield and yield components of potato in Shahrood. Journal of Research in Agricultural Science 7: 141-149. BISOGNIN, DA; DOUCHES, DS. 2002. Early 
generation selection for potato tuber quality in progenies of late blight resistant parents. Euphytica 127: 1-9.

BISOGNIN, DA; MUELLER, DR; STRECK, NA; ANDRIOLO, JL; SAUSEN, D. 2008. Desenvolvimento e rendimento de clones de batata na primavera enooutono. Pesquisa Agropecuária Brasileira 43: 699-705.

ESCHEMBACK, V; KAWAKAMI, J; MELO, PE. 2017. Performance of modern and old, European and Brazilian potato cultivars in different environments. Horticultura Brasileira 35: 377-384.

EVANGELISTA, RM. 2011. Qualidade nutricional e esverdeamento pós-colheita de tubérculos de cultivares de batata. Pesquisa Agropecuária Brasileira 46: 953-960.

FAGUNDES, JD. 2010. Aquecimento global: efeitos no crescimento, no desenvolvimento e na produtividade de batata. Ciência Rural 40: 1464-1472.

FELTRAN, JC; LEMOS, LB. 2005. Características agronômicas e distúrbios fisiológicos em cultivares de batata. Cientifica 33: 106-113.

FERNANDES, AM; SORATTO, RP; SILA, BL; SOUZA-SCHILICK, GD. 2010. Crescimento, acúmulo e distribuição de matéria seca em cultivares de batata na safra de inverno. Pesquisa Agropecuária Brasileira 45: 826835.

HASSANPANAH, D; HOSIENZADEH, AA; ALLAHYARI, N. 2009. Evaluation of planting date effects on yield and yield components of Savalan and Agria cultivars in Ardabil region. Journal of Food, Agriculture \& Environment 7: 525-528.

HAVERKORT, AJ; VERHAGEN, A. 2008. Climate change and its repercussions for the potato supply chain. Potato Research 51: 223-237.

KLEINWACHTER, U; CASTELO, M; RITCHIE, J; NELSON, GC; ASENG, S. 2016. Simulating cultivar variations in potato yields for contrasting environments. Agricultural Systems 145: 51-63.

MENEZES, CB; PINTO, CABP; LAMBERT, ES. 2001. Combining ability of potato genotypes for cool and warn season in Brazil. Crop Breeding and Applied Biotechnology 1: 145-157.

MICHALOVICZ, L; MULLER, MML; FOLONI, JSS; KAWAKAMI, J; NASCIMENTO, R; KRAMER, LFM. 2014. Soil fertility, nutrition and yield of maize and barley with gypsum application on soil surface in no-till. Revista Brasileira de Ciências do Solo 38: 1496-1505.

NARASIMHAMOORTHY, B; ZHAO, LQ; LIU, X; ESSAH, SYC; HOLM, DG; GREAVES, JA. 2013. Effect of harvest date on PI2, total protein, TGA content and tuber performance in potato. American Journal of Potato Research 90: 561-569.

PAUL, S; FAROOQ, M; GOGOI, N. 2016. Influence of high temperature on carbon assimilation, enzymatic antioxidants and tuber yield of different potato cultivars. Russian Journal of Plant Physiology 63: 319-325.

PEREIRA, AS. 2008. Batata: fonte de alimento para a humanidade. Horticultura Brasileira 26: 0-1.

PEREIRA, AS; BERTONCINI, O; SILVA, GO; CASTRO, CM; GOMES, CB; HIRANO, E; BORTOLETTO, AC; MELO, PE; MEDEIROS, CAB; TREPTOW, RO; DUTRA, LF;LOPES,CA;NAZARENO, NRX; MIRTEZ, FL; CASTRO, LAS; KROLOW, ACR; SUINAGA, FA; REISSER JUNIOR, C; 2013. BRS Clara: cultivar de batata para mercado fresco, com resistência à requeima. Horticultura Brasileira 31: 664-668.

PEREIRA, AS; DANIELS, J. 2003. O cultivo da batata na região sul do Brasil. Pelotas: Embrapa Clima Temperado; Brasília: Embrapa Informação Tecnológica. 567p.

PEREIRA, AS; SILVA, GO; BORTOLETTO, AC; HIRANO, E; CASTRO, CM; AZEVEDO, FQ; NAZARENO, NRX; SOUZA, ZS. 2015. Catálogo de cultivares de batata. Brasília: Embrapa. 51p. (Documents 373).

QUEIROZ, LRM; KAWAKAMI, J; MULLER, MML; OLIARI, ICR; UMBURANAS, RC; ESCHEMBACK, V. 2013. Adubação de NPK e tamanho de batata-semente no crescimento, produtividade e rentabilidade de batata. Horticultura Brasileira 31: 119-127.

RAYMUNDO, R; ASSENG, S; PRASSAD, R; KLEINWACHTER, U; CONCHA, J; CONDORI, B; BOWEN, W. 2017. Performance of the SUBSTOR-potato model across contrasting growing conditions. Field Crops Research 202: 57-76.

RYKACZEWSKA, K. 2015. The effect of high temperature occurring in subsequent stages of plant development on potato yield and tuber physiological defects. American Journal of Potato Research 92: 339-349.
SANTOS, KC; KAWAKAMI, J; GENÚ, AM; PASSOS, S; ESCHEMBACK, V. 2018. New national potato genotypes: yield response to different doses of 4-14-8 NPK fertilizer. Horticultura Brasileira 36: 106-111.

SILVA, FL; PEREIRA PINTO, CAB; ALVES, JD; BENITES, FRG; ANDRADE, CM; RODRIGUES, GB; LEPRE, AL; BHERING, LL. 2009. Caracterização morfofisiológica de clones precoces e tardios de batata visando a adaptação a condições tropicais. Bragantia 68: 295-302.

SILVA, GO; PEREIRA, AS; BAIL, FE; PONIJALEKI, R; CARVALHO, ADF. 2017. Resposta de cultivares de batata a níveis crescentes de NPK. Revista Ceres 64: 492-499.

SILVA, GO; PEREIRA, AS; SUINAGA, FA; PONIJALEKI, R. 2013b. Qualidade de pele e produtividade da cultivar de batata BRS Clara. Horticultura Brasileira 31: 613-617.

SILVA, GO; STOKER, G; PONIJALEKI, R; PEREIRA, AS. 2013a. Rendimento de tubérculos de três cultivares de batata sob condições de estiagem. Horticultura Brasileira 31: 216-219.

SIMEPAR.Sistema Meteorológico do Paraná. 2018. Available at $<\mathrm{http} / /$ :www.simepar.br $>$. Accessed January 02, 2018.

SOCIEDADE BRASILEIRA DE CIÊNCIA DO SOLO. 2017. Núcleo Estadual Paraná. Manual de adubação e calagem para o estado do Paraná. Curitiba: SBCS/NEPAR. 482 p.

WANG, C; SHEN, S; ZHANG, S; LI, Q; YAO, Y. 2015. Adaptation of potato production to climate change by optimizing sowing date in the Loess Plateau of central Gansu, China. Journal of Integrative Agriculture 14: 398-409.

WHITE, RP; SANDERSON, JP. 1983. Effect of planting date, nitrogen rate, and plant spacing on potato grown for processing in Prince Edward Island. American Potato Journal 60: 115-126.

ZANON, AJ; STRECK, NA; KRAEULICH, B; SILVA, MR; BISOGNIN, DA. 2013. Plant development and tuber yield in the potato in a subtropical climate. Ciência Agronômica 44: 858-868.

ZHANG, K; WANG, R; LI, Q; ZHAO, H; WANG, H; GUO, L; ZHANG, X. 2012. Effects of sowing date on the growth and tuber yield of potato in semi-arid area of loess plateau in central Gansu Province of Northwest China. Chinese Journal of Ecology 31:2261-2268. 